\title{
Crop-Livestock Competition in the West African Derived Savanna: Application of a Multi-objective Programming Model ${ }^{*}$
}

\author{
Victor Okoruwa, ${ }^{a}$ M. A. Jabbar ${ }^{b \dagger} \&$ J. A. Akinwumi ${ }^{a}$ \\ "Department of Agricultural Economics, University of Ibadan, Ibadan, Nigeria \\ ${ }^{b}$ International Livestock Research Institute, P.O. Box 5689, Addis Ababa, Ethiopia
}

(Received 17 August 1995: accepted 19 December 1995)

\begin{abstract}
$A B S T R A C T$
In West Africa, crop-livestock mixed farming is emerging from the currently predominant nomadic pastoralism and agropastoralism. It is hypothesized that competitiveness between crop and livestock enterprises may be an important determinant of the pace of this evolution. A field study in the derived savanna of southwest Nigeria shows that at the current stage of evolution, as a crop farmer adds livestock to his business, there is a small gain in the beginning, then an increasing rate of substitution between crop and livestock follow. As a livestock rearer engages in crop production, there is a decreasing rate of substitution between livestock and crop. This situation derives from the fact that crop production is more intensive than livestock production, which depends principally on grazing natural pastures. Results indicate that if increased population pressure and cropping intensity severely limit access to grazing land, farm and herd sizes will become smaller, then the degree of integration between crop and livestock will increase significantly. Copyright 1996 Elsevier Science Ltd
\end{abstract}

\section{INTRODUCTION}

Transhumant pastoralism made cattle production viable in the ecological stratification of West Africa. Although it is still the dominant system of

*Derived from the first author's $\mathrm{PhD}$ thesis titled 'The economics of agropastoral production systems in the derived savannah of Oyo State, Nigeria' submitted to the University of Ibadan, Nigeria, in August 1994.

${ }^{\dagger}$ To whom correspondence should be addressed. 
cattle production in the region, this traditional system is breaking down because of the population explosion in recent decades and cycles of low rainfall, drought, and shortage of fertile land in the Sahel.

Several authors have postulated population pressure as the prime mover for agricultural intensification and development of crop-livestock farming (Boserup, 1965, 1981; Ruthenberg, 1980; Pingali et al., 1987; McIntire et al., 1992). Market access, access to improved technology packages, presence of cash crops, dominance of cereals in the cropping pattern, and relative prices have been mentioned as additional factors fostering intensification and crop-livestock interaction in specific situations (de Wilde, 1967; McIntire et al., 1992; Smith et al., 1993).

Population pressure and climatic changes in the Sahel have caused major changes in the pattern of livestock ownership and agricultural production. An increasing proportion of stock in the Sahel is now owned by crop farmers, who invested their surplus revenue from crop sales in animal production when crop prices were higher. They also took advantage of low livestock prices during droughts to acquire animals from poor farmers or pastoralists. Although the process has fostered crop-livestock integration into mixed farming, it has also created problems for pastoralists. Pastures in the crop zone and crop residues hitherto accessible to pastoralists are now used by village-based livestock. Even marginal pasture lands are brought under cultivation due to population pressure, making pastoral livestock rearing difficult (Speirs \& Olsen, 1992).

One response to this crisis has been for many pastoralists to move south into the moist savannah zone, where crop residues and pastures are plentiful, and in recent times the risk of trypanosomiasis and other diseases has declined due to tsetse control measures as well as land clearance for expanded crop production (Putt et al., 1980; Bourn, 1983). Consequently, crop-livestock interaction and integration are evolving in the moist savannah zone from two directions. The dominant line is that of the nomadic pastoralist becoming a sedentary pastoralist and eventually an agropastoralist, who produces crops and raises cattle principally by grazing natural pastures. Milk sales are the source of regular cash income. Herd size tends to decline with period of settlement and more involvement in crop farming. A minor but perceptible line is that of the crop farmer purchasing a few cattle and first giving them to Fulani herdsmen for management or hiring Fulani herdsmen for management, then taking up management themselves after gaining experience. Milk production or manure is not yet the primary motive of the crop farmer investing in cattle. Income from herd growth, fattened animal sales, and in drier areas, benefit of traction, are the primary motives for investment in the rearing of cattle. Manure is considered a secondary benefit. These crop-cattle farmers cannot yet technically and 
economically compete with the pastoralists and agropastoralists in milk production. Given the low productivity of indigenous dairy cows, the advantage of the nomadic and sedentary pastoralists is derived from their ability to raise cattle on the basis of an almost zero cost of grazing, their ability to move to adapt to seasonal feed needs, and to take advantage of the poorly developed market in a flexible manner (Jabbar, 1993; Jabbar et al. . 1995)

In such a situation, the pace of evolution of agropastoralism into integrated mixed farming will be strongly influenced by, among other factors, the nature of trade-off or competitiveness between crop and livestock enterprises. The pace will be slow if adequate access to free grazing pasture land remains a major option. In order to test this hypothesis, a study was conducted in the derived savannah of southern Nigeria, where agropastoralism and adoption of cattle by crop farmers are emerging. The derived savannah is a transitory zone between the humid zone and southern Guinea savannah; in other words, it lies on the wetter end of moist savannah.

\section{METHOD}

Data were collected in 1992 by a multiple visit survey from 63 agropastoralists and 20 crop farmers selected from the derived savannah region of Oyo State, southwest Nigeria (for a more detailed description of the sample distribution and procedure, see Okoruwa (1994)). Among the agropastoralists, 31 owned cattle, 24 owned as well as managed cattle for other farmers on a caretaking basis, and eight managed cattle for other farmers on a caretaking basis. Nearly all the sample households had small ruminants, mostly owned, but a few households had an additional number of small ruminants kept on a caretaking basis. Agropastoralists raised cattle principally on grazing natural pastures and grazing a certain amount of crop residues.

Profitability of crop and livestock enterprises under different systems of management were measured by applying farm budgeting procedures. Among other things, the implication of charging a rent or tax for grazing land was examined. Then a mixed integer linear programming model was used to test whether available land, labour and capital resources were efficiently allocated by the different farm groups. The general form of the model for a system is as follows:

$$
\text { Maximize } Z=\sum_{j=1}^{n} c_{j} x_{j}
$$




$$
\begin{gathered}
\text { Subject to } \sum_{j=1}^{n} a_{i j} x_{j} \leq G_{i}, i=1,2, \ldots, m ; \\
x_{j} \geq 0, j=1, \ldots n
\end{gathered}
$$

where

$$
\begin{aligned}
Z & =\text { total gross margin of a production system, } \\
c & =\text { gross margin per unit activity } j \\
x & =\text { level of activity } j \\
a & =i \text { th resource requirement per unit activity } j, \\
G & =\text { supply of } i \text { th resource. }
\end{aligned}
$$

Models were developed for four production systems (three agropastoral and one crop farming systems as described above). In general, four livestock activities (cattle owning, cattle caretaking, goat owning, sheep owning), six crop production activities (sole maize, maize-sorghum-yam mixed, maize-cassava mixed, maize-yam mixed, pepper-tomato mixed, and sole okro), and the following resource restrictions were used:

$\mathrm{G} 1=$ grazing/range land available (ha)

$\mathrm{G} 2$ = number of livestock units (TLU)

$\mathrm{G} 3=$ crop land available (ha)

G4 = amount of manure available (tonnes)

G5-8 = family labour (man-days) available in quarters 1 (Jan-March), 2 (April-June,) 3 (July-September), 4 (October-December)

G9 = total hired labour available (man-days)

$\mathrm{G} 10=$ total amount of capital available (Naira)

G11 = amount of manure available from night kraaling (tonnes)

G12-15 = minimum amount of maize, sorghum, cassava and yam respectively to be produced for home consumption (tonnes).

Among the four livestock activities considered, cattle caretaking was not relevant for the cattle owning agropastoralist model, cattle owning was not relevant for the cattle caretaking agropastoralist model, and none of the cattle activities were relevant for the crop farmer model. Caretaking of small ruminants was not considered a separate activity because this is not a significant separate activity in the area. Cattle are not yet used for draft purposes in the study area, so value of draft or draft as an input in crop production was not considered.

In this generalized model, all the designated activities are perfect substitutes. As one or more resource constraint limits the level of production of an activity, the optimization process searches for the next best activity, irrespective of whether it is a crop or a livestock activity. In reality, farmers with the same bundle (composition, quantity and quality) of resources may 
devote different proportions of resources to crop and livestock enterprises, and may try to maximize total returns by optimizing allocation within crop and livestock enterprise groups before switching resources between crop and livestock. Under such a condition, the trade-off between crop and livestock may be measured by the net benefits of switching resources between crop and livestock on the margin. Problems of this nature can be solved by multiple objective programming (MOP) methods, whereby several objectives are simultaneously optimized, subject to a set of constraints, which are usually linear (Marglin, 1967; Freeman \& Haveman, 1970; Dasgupta et al., 1972; Cohon et al., 1979; Romero \& Rehman, 1984, 1985; Tabucanon, 1993; Zhu et al., 1993; I ara \& Romero, 1994). MOP differs from simple LP in that it essentially deals with more than one objective function. As an optimum solution cannot be defined for several simultaneous objectives, MOP seeks to find the set of efficient solutions, also called non-dominated or non-inferior or Pareto optimal solutions, rather than locate the single optimal solution. The set of non-inferior solutions defines the relative boundary of the feasible region. The optimum investment plan solution chosen by the decision-maker out of the set of efficient solutions depends on the preferences that the decision-maker attaches to each objective, that is, the subjective values of trade-offs between the objectives. The slope of the line connecting the efficient points represents the actual values of the trade-off between the objectives (Freeman \& Haveman, 1970; Romero \& Rehman, 1985; Tabucanon, 1993).

The non-inferior solutions to a multi-objective problem can be generated in a number of ways:

- The multi-objective simplex method, in which all the extreme noninferior solutions are obtained by moving from one extreme solution (point) to the adjacent extreme solution (point) by a simplex 'pivoting'operation. If the extreme point is efficient, it is stored, otherwise it is eliminated (Evans \& Steuer, 1973; Zeleny, 1974; Tabucanon, 1993; Steuer, 1994).

- The weighted method, in which the objective function is defined as a weighted sum of the multiple objectives, and the non-inferior solutions are obtained by parameterizing the weights (Marglin, 1967).

- The constraint method, in which one of the objectives is optimized whereas the rest are specified as constraints, the non-inferior solutions being obtained by parameterizing.

- The right-hand side of the objectives placed as constraints (Cohon \& Marks, 1973, 1975; Cohon, 1978).

- The non-inferior set estimation method, which uses a common LP code iteratively (Cohon et al., 1979). This method actually works only for bi-objective problems. 
The constraint method was used in the present study to measure tradeoff or competitiveness between crop and livestock production. This method is simple yet efficient (Cohon, 1978). The LP model described earlier was modified by distinguishing and separating crop and livestock activities in the objective function and by incorporating a weighting technique in the supply side of the model, rather than in the objective function, for a parametric variation of resource allocation between crop and livestock to generate the trade-off function. The general form of the modified model may be expressed as:

$$
\begin{aligned}
& \text { Maximize } Z=\sum_{j=1}^{K} c_{j} x_{j}+\sum_{J=K+1}^{n} c_{j} x_{j} \\
& \text { Subject to } \sum_{j=1}^{K} a_{i j} x_{j} \leq G_{i}(r), i=1, \ldots m \text {; } \\
& \sum_{j=k+1}^{n} a_{i j} x_{j} \leq G_{i}(1-r), i=1, \ldots m \text {; } \\
& x_{j} \geq 0, j=1, \ldots . n ;
\end{aligned}
$$

where

$j=1$ to $k$ are livestock activities,

$j=k+1$ to $n$ are crop activities,

$r=$ proportion of a resource allocated to livestock activities,

$1-r=$ proportion of a resource allocated to crop activities.

Other notations are as defined earlier for the LP model. The value of $r$ ranges from 0 to 1 and defines the relative weight given to crop and livestock production. For all values of $r$ between 0 and 1 , the objective function is maximized at different weighted supply combinations, e.g. when $r$ $=0 \cdot 1$, the function is maximized with livestock and crop weighted in the ratio of 1:9. In order to draw a smooth trade-off curve, ideally continuous values of $r$ should be used. However, discrete values of $r$ were actually used in this study and the trade-off curve was derived by joining relevant points.

\section{RESULTS AND DISCUSSION}

\section{Farm budgets}

The sample households had similar family sizes and labour supply (Table 1). Agropastoralist groups had similar amounts of cropland, which was 
TABI.E 1

Characteristics of Agropastoralists and Crop Farmers

\begin{tabular}{|c|c|c|c|c|}
\hline \multirow[t]{2}{*}{ Characteristic } & \multicolumn{3}{|c|}{ Agropastoralists } & \multirow[t]{2}{*}{ Crop farmer } \\
\hline & Cattle onner & $\begin{array}{l}\text { Cattle owner } \\
\text { and caretaker }\end{array}$ & $\begin{array}{c}\text { Cattle } \\
\text { caretaker }\end{array}$ & \\
\hline No. of sample & 31 & 24 & 8 & 20 \\
\hline Average family size & $11 \cdot 2$ & $12 \cdot 1$ & 11.0 & 11.2 \\
\hline Average family labour, man-units & $6 \cdot 3$ & $6 \cdot 7$ & $6 \cdot 9$ & $6 \cdot 7$ \\
\hline Total cropland/farm, (ha) & 3.7 & 3.5 & $3 \cdot 8$ & 5.1 \\
\hline Fallow land/farm, (ha) & 1.4 & $1 \cdot 2$ & 1.4 & 1.8 \\
\hline Land use intensity & 0.62 & 0.66 & 0.63 & 0.65 \\
\hline Crops produced/farm, ha & $2 \cdot 30$ & $2 \cdot 30$ & $2 \cdot 40$ & $3 \cdot 30$ \\
\hline Sole maize & 0.51 & 0.55 & 0.40 & 0.61 \\
\hline Maize-cassava mixed & 0.68 & 0.81 & 0.84 & 0.77 \\
\hline Maize-sorghum-yam mixed & 0.61 & 0.52 & 0.68 & 1.03 \\
\hline Maize-yam mixed & 0.38 & $0 \cdot 20$ & 0.44 & 0.72 \\
\hline Tomato-pepper mixed & 0.05 & 0.10 & 001 & 0.12 \\
\hline Sole okro & 0.07 & 0.12 & 0.03 & 0.05 \\
\hline Cattle/farm. number & 27.5 & $33 \cdot 7$ & $21 \cdot 6$ & $\ldots$ \\
\hline Small ruminants/farm, number & 14.7 & $13 \cdot 3$ & $16 \cdot 2$ & 7.6 \\
\hline
\end{tabular}

significantly lower than that for crop farmers. Land use intensity, i.e. proportion of available land cultivated in a year, was also similar across groups. Allocation of cropland to various crop or crop mixes was fairly similar among the groups. The number of cattle and small ruminants managed (owned + caretaken) per farm did not differ significantly $(P>0.05)$ among the three agropastoralist groups. Crop farmers had about half the number of small ruminants owned by each of the agropastoralist group.

Gross revenue per farm averaged $64,578,56,875,55,896$ and 53,982 Naira for cattle owning, cattle owning and caretaking, cattle caretaking and crop farming households (Table 2). Livestock accounted for 35\%, 27\%, 18\% and $2 \%$ of gross revenue for the respective groups. Milk accounted for $60.68 \%$ of livestock revenue, indicating low offtake (sales) of livestock.

Agropastoralist groups on average spent the equivalent of $3-13 \%$ of livestock revenue as variable costs for livestock and $18-23 \%$ of crop revenue as variable costs for crops (Table 2). Crop farmers spent on average the equivalent of $26 \%$ of crop revenue as variable costs for crops. These are indications of less cash input-based production methods used by agropastoralists compared to crop farmers. Consequently, agropastoralists, particularly cattle owning farmers, had significantly higher gross margins than crop farmers. Gross margin per farm was, respectively, $52,752,45,782,47,140$ and 40,156 Naira for the four groups. However, cattle owners and cattle owners and caretakers had significantly lower net farm income (return to family labour and management) than cattle caretaking 
TABLE 2

Average Costs and Returns (Naira) Per Farm for Agropastoralists and Crop Farmers

\begin{tabular}{lrrrr}
\hline Costs and returns & \multicolumn{3}{c}{ Agropastoralists } & Crop farmer \\
\cline { 2 - 5 } & Cattle owner Cattle owner & $\begin{array}{c}\text { Catte } \\
\text { and caretaker }\end{array}$ & \\
caretaker & \\
Gross revenue & & & & \\
Livestock & 22,565 & 15,380 & 9,807 & 1,000 \\
Crop & 42,013 & 41,495 & 46,089 & 52,982 \\
Total & 64,578 & 56,875 & 55,896 & 53,982 \\
\hline Variable cost & & & & \\
Livestock & 2,271 & 1,978 & 225 & 35 \\
Crop & 9,555 & 9,115 & 8,531 & 13,791 \\
Total & 11,826 & 11,093 & 8,756 & 13,826 \\
\hline Gross margin & & & & \\
Livestock & 20,294 & 13,403 & 9,775 & 965 \\
Crop & 32,459 & 32,380 & 37,558 & 39,191 \\
Total & 52,752 & 45,782 & 47,140 & 40,156 \\
\hline Fixed cost & & & & \\
Land & 369 & 350 & 380 & 513 \\
Capital & 25,898 & 21,552 & 3,014 & 2,616 \\
Total & 26,267 & 21,902 & 3,394 & 3,129 \\
\hline Net farm income & 26,485 & 23,880 & 43,746 & 37,027 \\
\hline
\end{tabular}

US\$1 = Naira 18.60 in 1992.

farms and crop farms, because cattle owners had higher opportunity costs of capital tied up in cattle, whereas cattle caretakers did not have such costs. If a rent was charged for grazing land at the same rate as cropland, net income (return) would be reduced by $10-12 \%$.

Average net return per man-day of family labour was 24, 20, 37 and 26 Naira for the four groups (Table 3). These rates were competitive with prevailing wage rates in the study area.

\section{Optimality in resource allocation: LP model outcomes}

Table 4 shows expected activities and returns generated by the LP models for different groups. Expected gross margins were 15-22\% higher than those actually observed from farm budgets for the year (Table 2). Expected enterprise choices show some significant deviations from the actual combinations found in the year (Table 1). Whereas sole maize was a major and sole okro a minor enterprise in actual farm practice, neither were chosen by the LP solution. The LP solution also devoted a significantly 
TABI.F 3

Per Caput Gross Margin And Net Income (Naira)

Agropastoralists
Cattle onner Cattle owner farmer
and caretaker caretaker

\begin{tabular}{lrrrr}
\hline Gross margin & & & & \\
per caput & 4710 & 3784 & 4285 & 3585 \\
per man-day & 48 & 38 & 40 & 28 \\
Net income & & & & \\
per caput & 2365 & 1974 & 3977 & 3306 \\
per man-day & 24 & 20 & 37 & 26 \\
\hline
\end{tabular}

TABLE 4

Optimum Enterprise Combinations and Returns for Agropastoralists and Crop Farmers Activities/returns

\begin{tabular}{cccc} 
Agropastoralists & Crop farmer \\
\cline { 1 - 2 } Cattle owner Cattle onner & $\begin{array}{c}\text { Cattle } \\
\text { and caretaker }\end{array}$ & \\
caretaker & \\
19 & 16 & - & - \\
-10 & 8 & 15 & - \\
5 & 9 & 11 & 2 \\
- & 4 & 5 & 6 \\
0.29 & - & - & - \\
1.90 & 0.33 & 0.30 & 0.38 \\
0.11 & 1.78 & 1.82 & 2.10 \\
- & - & 0.04 & 0.4 \\
- & 0.19 & 0.24 & 0.42 \\
60.813 & 56.069 & 55.926 & -47.212
\end{tabular}

higher amount of land to mixed sorghum and yam production for all the four groups of farms than was actually found in practice. Note that minimum amounts of maize, sorghum, cassava and yam production for home consumption were built into the models. Without this restriction, the theoretical optimum (enterprise combination and returns) would deviate further from actual practice. Yam and sorghum being relatively higher value crops in the study area, a less subsistence and more marketoriented production goal would entail more specialized enterprise choices and high returns than were actually observed. This is an indication that, with current resource bundles and unchanged market prices, there was some untapped opportunity for increasing farm income.

It was mentioned earlier that in the study area, crop-cattle farming is emerging and that cattle are raised mainly by grazing natural pasture. As 
TABLE 5

Optimum Enterprise Combinations and Returns Under Larger and Smaller Access to Grazing Land for Agropastoralists

\begin{tabular}{|c|c|c|c|c|c|c|}
\hline \multirow[t]{3}{*}{ Activities/returns } & \multicolumn{6}{|c|}{ Cattle owner } \\
\hline & \multicolumn{2}{|c|}{ Cattle owner } & \multicolumn{2}{|c|}{ Caretaker } & \multicolumn{2}{|c|}{ Catule caretaker } \\
\hline & $\begin{array}{l}\text { Larger } \\
\text { access }\end{array}$ & $\begin{array}{c}\text { Smaller } \\
\text { access }\end{array}$ & $\begin{array}{l}\text { Larger } \\
\text { access }\end{array}$ & $\begin{array}{c}\text { Smaller } \\
\text { access }\end{array}$ & $\begin{array}{l}\text { Larger } \\
\text { access }\end{array}$ & $\begin{array}{c}\text { Smaller } \\
\text { access }\end{array}$ \\
\hline Own cattle. TLU & 35 & 8 & 29 & 8 & - & $\ldots$ \\
\hline Caretaking cattle, TLU & 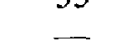 & - & 8 & - & 25 & 8 \\
\hline Sheep, no & 10 & 10 & 9 & 9 & 11 & 11 \\
\hline Goats, no & 5 & 5 & 4 & 4 & 5 & 5 \\
\hline Sole maize, ha & 0.12 & - & 0.44 & - & - & - \\
\hline Maize-cassava, ha & 0.29 & 0.29 & 0.33 & 0.33 & $0 \cdot 30$ & $0 \cdot 30$ \\
\hline Maize-sorghum-yam, ha & 1.88 & 1.61 & 1.33 & 0.99 & 2.04 & 1.35 \\
\hline Maize-yam, ha & - & 0.04 & 0.05 & 0.11 & - & 0.15 \\
\hline Tomato-pepper, ha & - & 0.35 & 0.15 & 0.87 & 0.06 & 0.59 \\
\hline Sole okro, ha & - & - & 0.15 & - & - & - \\
\hline Gross margin, N & 73,213 & 51,089 & 58,853 & 50,803 & 59,023 & 53,358 \\
\hline
\end{tabular}

population density and cropping intensity increase, and as more people adopt crop-cattle farming, access to natural grazing land becomes more limited, requiring more labour to tether animals carefully, and, at a later stage, harvest and feed crop residues. This has implications for the size of herd that can be managed and crop-mixes that can be produced.

In order to assess the impact of larger and smaller access to grazing land than that the three agropastoralist groups actually had in the study year, the basic LP models for these three groups were re-run by doubling the current level of access to pasture land, indicating a more extensive cattle production option, and by reducing the access to pasture land to half the current level, indicating a more intensive production option. The results show that larger access to grazing land increases cattle numbers and gross margin for all the three agropastoral groups, but the effect on crop mixes is different (Table 5). The optimum crop mixes change very little for cattle owners, become more diversified for cattle owners and caretakers, and become less diversified for cattle caretakers. On the other hand, smaller access to grazing land reduces cattle numbers and gross margin significantly and makes crop mixes more diversified for all three agropastoral groups. Different grazing labour requirements, in terms of quantity and schedule, under larger and smaller access to grazing land situations appeared to be a key factor in determining herd size and crop-mixes.

The results in relation to restricted access to grazing land are of greater practical significance for the emerging situation in the study area and for 
TABLE 6

Optimum Enterprise Combination and Returns of Agropastoralists from Trade-off Functions

\begin{tabular}{|c|c|c|c|}
\hline Activities/returns & Catle onner & $\begin{array}{l}\text { Cattle owner } \\
+ \text { caretaker }\end{array}$ & $\begin{array}{c}\text { Cattle } \\
\text { caretaker }\end{array}$ \\
\hline Own cattle, TLU & 8 & - & - \\
\hline Caretaking cattle, TLU & - & - & 5 \\
\hline Sheep, number & - & - & 11 \\
\hline Goat, number & - & - & 5 \\
\hline Sole maize. ha & - & 4.67 & 0.01 \\
\hline Maize cassava mixed, ha & 0.29 & $0 \cdot 33$ & $0 \cdot 30$ \\
\hline Maize-sorghum-yam mixed, ha & $2 \cdot 71$ & 0.63 & $3 \cdot 25$ \\
\hline Maize-yam mixed, ha & 0.50 & 0.17 & 0.23 \\
\hline Tomato-pepper mixed, ha & - & 一 & - \\
\hline Sole okro, ha & - & - & - \\
\hline Gross margin (Naira) & 68,726 & 66,530 & 71,996 \\
\hline
\end{tabular}

the long-term behaviour of the agropastoralists. Two earlier surveys in the same area for understanding the process of sedentarization of cattle farmers indicated that nomadic pastoralists generally have large herds, but as they settle and engage in crop production alongside raising cattle, herd size gradually decreases as the period of settlement increases. Management of large herds without mobility becomes difficult, so increased involvement in crop production essentially requires reduction of herd size, grazing in nearby limited areas and using crop residues as feed supplements (Jabbar, 1993; Jabbar et al., 1995). Given small land holdings, greater integration of crops and cattle takes place with smaller herd size and intensive crop production.

\section{Trade-off between crop and livestock production: MOP outcome}

In applying the constraint method to measure crop-livestock competition, two extreme situations were first considered: all the available resources were either allocated to crop production or to livestock production. Then different values of $r$ (share of resources devoted to livestock or crop) were chosen for production resources, the combined optimum solutions were derived for each combination and the values were plotted to obtain the trade-off or transformation curve. Minimum home food production was not imposed as in the LP model.

The results show that a livestock farmer under any system of cattle management (owning, owning plus caretaking, caretaking) cannot engage in crop production without first losing some income from livestock (Table 6 and Fig. 1). On the other hand, a crop farmer may add a small income initially by engaging in livestock rearing; the relationship becomes competitive as a higher proportion of resources are devoted to livestock. Results indicate 


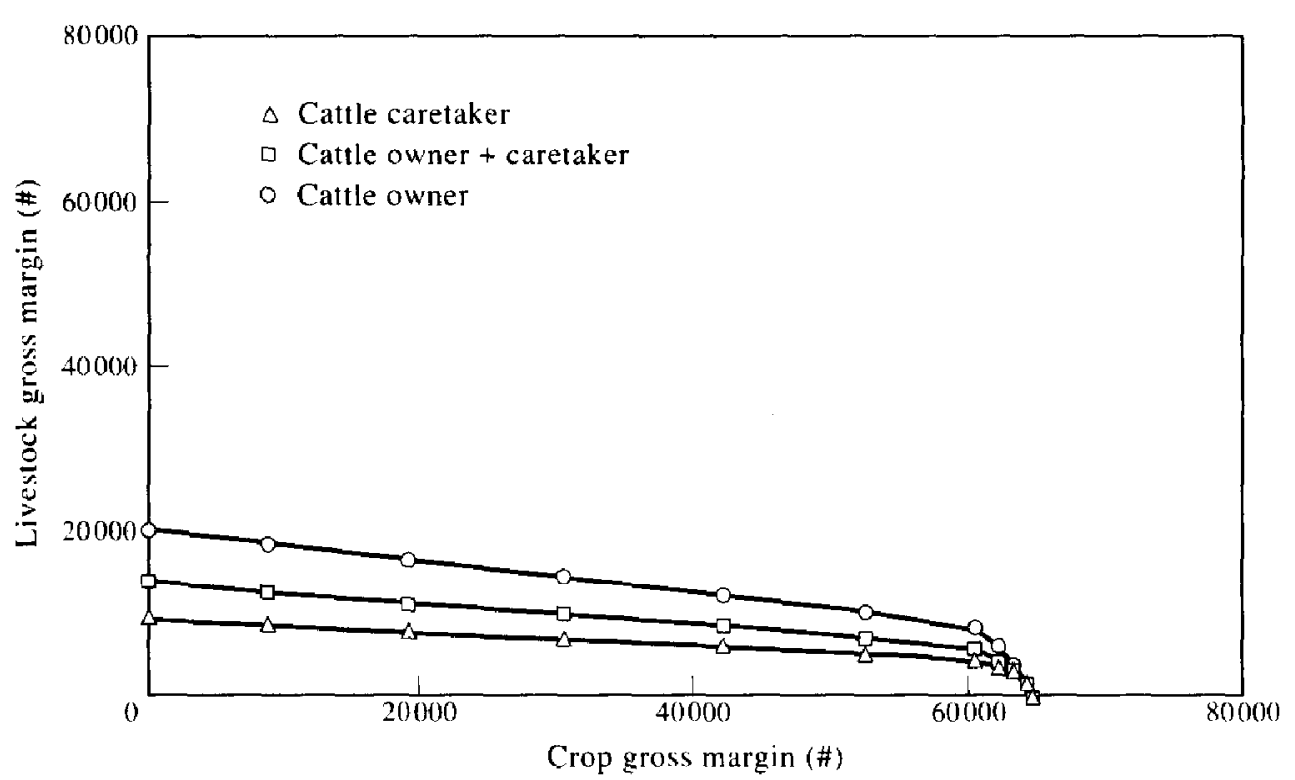

Fig. 1. Trade-off between crop and livestock enterprises under different systems of cattle management.

that, compared to the present situations (Tables 1 and 2) and LP model outcome (Table 4), cattle owners and caretakers can significantly increase gross margins by drastically reducing herd size and devoting more land and labour to crop production (Table 6). The cattle owning and caretaking group can also significantly increase gross margins by completely giving up cattle. However, under all three systems of cattle management, the nature of competition between crop and livestock indicates that under conditions of small land holding, the optimum crop-cattle combination requires a small cattle herd size and the allocation of a high proportion of land and labour to crop production. This confirms the LP model outcomes with restricted access to grazing land, as explained earlier, and the survey findings that the herd size of agropastoralists declines over the long term as they engage more intensively in crop production.

In the farm budget analysis, it was shown that farmers currently use some productivity increasing variable inputs, e.g. fertilizers, in crop production but very little in livestock production. The implication of increased use of productivity increasing variable inputs in livestock production, e.g. drugs and better feeds, for crop-livestock competition was examined. This was done in two ways. First, quantity and expenditure on drugs and purchased feeds were doubled from the current low level, and based on experimental data, it was assumed that for each Naira of additional investment, extra output worth 6 Naira would result due to reduced mortality, increased weight gain and milk yields. These were then reflected in increased gross margin for livestock. Second, expenditure on drugs was increased but 


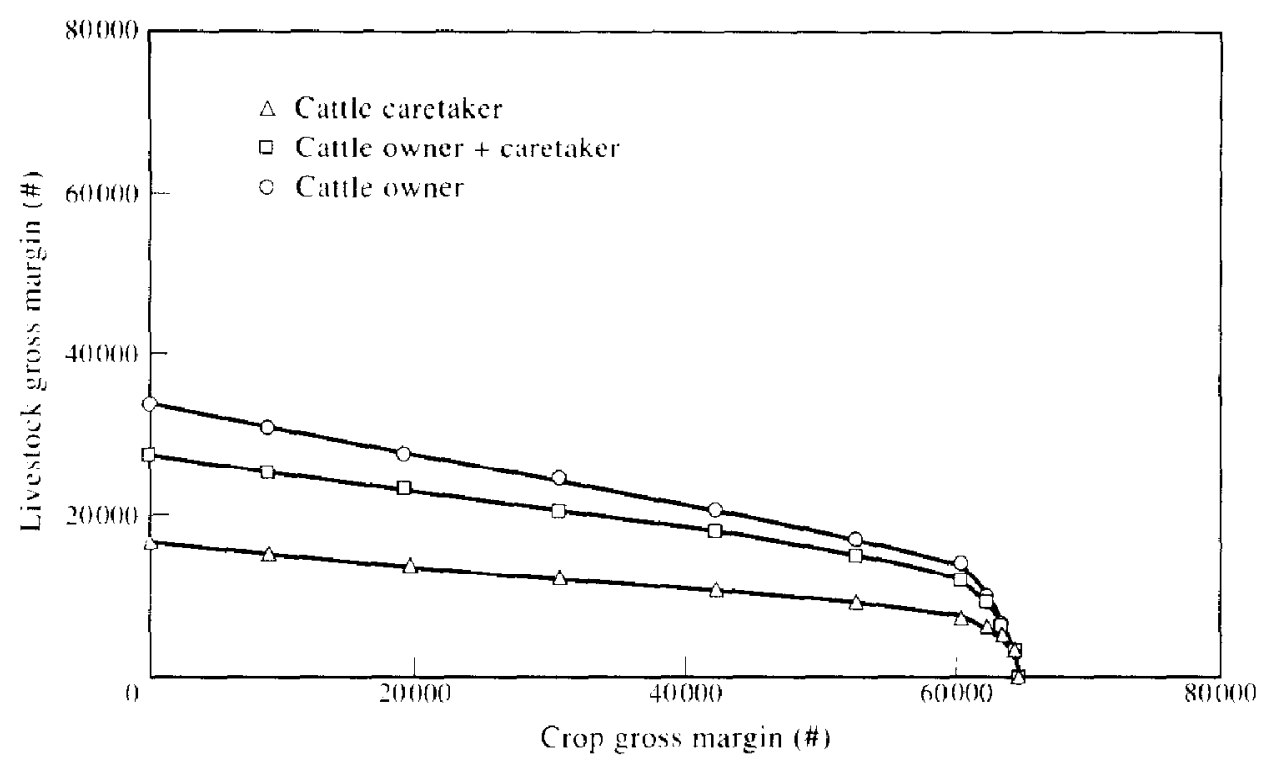

Fig. 2. Trade-off between crop and livestock enterprises under different systems of cattle management with purchased feed.

rather than purchasing feed, production of minimum quantities of certain high quality crop-residues (e.g. maize and cowpea) on-farm was imposed in the model (in the same way as minimum food production for home consumption was imposed in the LP model). Assuming that the high quality residues would be supplemented during the critical 4-month dry season, possible weight gains were postulated on the basis of experimental data. These were then converted into values and reflected in increased gross margins for livestock. The stepwise procedure, assuming different values of $r$, was then followed to obtain the transformation curves.

Results show that, irrespective of whether feed was purchased or produced, livestock became more profitable and competitive (the transformation curves became steeper) due to increased productivity (Figs 2 and 3). In option 2, where on-farm feed production was imposed, choice of optimum crop-mixes altered significantly from the current practice and from other models examined earlier. Changing cropping pattern to produce feed was more profitable than purchasing feed, especially for cattle owners. However, grazing natural pasture still remained the major feed source under these models. If increased population pressure and cropping intensity severely limit access to grazing land, livestock production will be more intensive and costly as was observed earlier (Table 4), so that its competitiveness with crops will be reduced. Only then will the degree of integration between crops and livestock increase significantly, and a more balanced allocation of resources between crop and livestock will take place. 


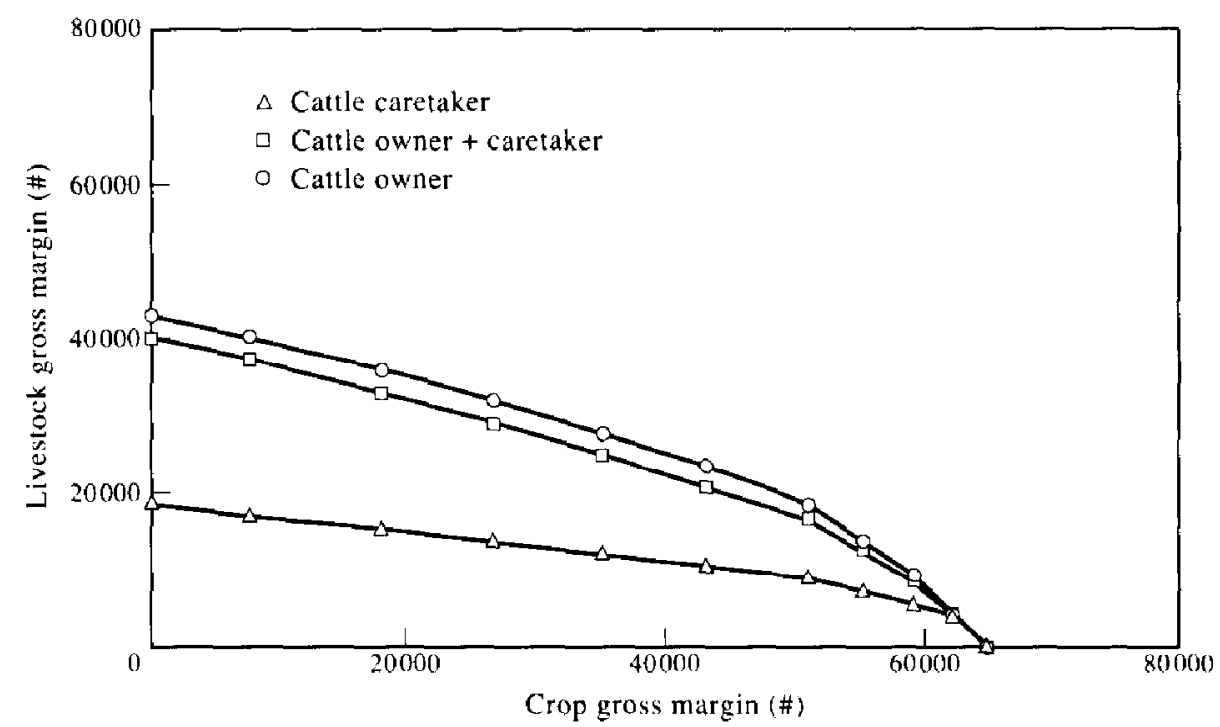

Fig. 3. Trade-off between crop and livestock enterprises under different systems of cattle management with produced feed.

\section{ACKNOWLEDGEMENTS}

Comments of the Editor and two anonymous referees on an earlier draft are gratefully acknowledged.

\section{REFERENCES}

Boscrup, E. (1965). The Conditions of Agricultural Growth: The Economics of Agrarian Change under Population Pressure. Aldine, New York.

Boserup, E. (1981). Population and Technological Change: A Study in Long-term Trends. University of Chicago Press, Chicago.

Bourn, D. M. (1983). Tsetse control, agricultural expansion and environmental change in Nigeria. Dphil thesis, Christ Church College, Oxford, England.

Cohon, J. L. (1978). Multiobjective Programming and Planning. Academic Press, New York.

Cohon, J. L. \& Marks, D. H. (1985). A review and evaluation of multi-objective programming technique. Water Resources Research, 11(2), 208-220.

Cohon, J. L. \& Marks, D. H. (1975). Multi-objective screening models and water resource investment. Water Resources Research, 9(4), 826-836.

Cohon, J. L., Richard, L. C. \& Daniel, P. S. (1973). Generating multiobjective trade-offs: an algorithm for bicriteria problems. Water Resources Research, 15(5), $1001-1010$.

Dasgupta, P., Sen, A. K. \& Marglin, S. (1972). Guidelines for Project Evaluation. UNIDO, New York, U.S.A.

de Wilde, J. C. et al. (1967). Experiences with Agricultural Development in Tropical Africa (2 vols). The Johns Hopkins University Press, Baltimore.

Evans, J. P. \& Steuer, R. E. (1979). A revised simplex method for linear multiple objective problem. Mathematical Programming, 5(1), 54-72. 
Freeman, A. M. \& Haveman, R. H. (1973). Benefit cost analysis and multiple objectives: Current issues in water research planning. Water Resources Research, 6(6), 1533-1539.

Jabbar, M. A. (1970). Evolving crop-livestock farming systems in the humid zone of West Africa: potential and research needs. Outlook on Agriculture, 2(1), 13-21.

Jabbar, M. A., Reynolds, L. \& Francis, P. A. (1993). Sedentarization of cattle farmers in the derived savannah region of southwest Nigeria: results of a survey. Tropical Animal Health and Production, 27, 55-64.

Lara, P. \& Romero, C. (1995). Relaxation of nutrient requirements on livestock rations through interactive multigoal programming. Agricultural Systems, 45(4), 53-445.

Marglin, W. L. (1967). Public Investment Criteria. Allen and Unwin, London.

McIntire, J., Bourzat. D. \& Pingali, P. (1992). Crop Livestock Interactions in sub-Saharan Africa. World Bank, Washington, DC.

Okoruwa, V. (1994). The economics of agropastoral production systems in the derived savannah of Oyo State, Nigeria. Unpublished PhD. thesis, Department of Agricultural Economics, University of Ibadan, Nigeria.

Pingali, P., Bigot, Y. \& Binswanger, H. P. (1987). Agricultural Mechanization and the Evolution of Farming Systems in sub-Saharan Africa. World Bank, Washington, DC.

Putt, S. N. H., Shaw, A. P. N., Mathewman, R. W., Bourn, D., Underwood, M., James, A. D., Hallam, J. \& Ellis P. R. (1980). The social and economic implications of trypanosomiasis. Study No. 25. University of Reading, Reading, England.

Romero, C. \& Rehman, T. (1994). Goal programming and multiple criteria decision making in farm planning: an expository analysis. Journal of Agricultural Economics, 35(2), 177-190.

Romero, C. \& Rehman, T. (1984). Goal programming and multiple criteria decision making in farm planning: some extensions. Journal of Agricultural Economics, 36(2), 171-186.

Ruthenberg, H. (1980). Farming systems in the tropics. Clarendon Press, Oxford.

Smith, J., Barau, A. D., Goldman, A. \& Marek, J. H. (1993). The role of technology in agricultural intensification: the evolution of maize production in the northern Guinea savannah of Nigeria. In Social Science Research in Technology Development: Spatial and Temporal Dimensions, ed. K. A. Dovarak. CAB International, Oxon, pp. 144-166.

Speirs, M. \& Olsen, O. (1992). Indigenous Integrated Farming Systems in the Sahel. World Bank Technical Paper No. 179. Africa Technical Department Series. World Bank, Washington, DC.

Steuer, R. E. (1994). Manual for the ADBASE. Multiple Objective Linear Programming Package. Faculty of Management Science, University of Georgia, Athens, GA.

Tabucanon, M. T. (1993). Application of multiple criteria decision making methodology in food policy analysis. In Food Security and Food Inventories in Developing Countries. P. Berck and D. Biguan, eds. CAB International, Wallingford, U.K. pp. 151-174.

Zeleny, M. (1974). Linear Multiobjective Programming. Springer-Verlag, New York, USA.

Zhu, M., Taylor, D. B. \& Sarin, S. C. (1985). Multiobjective dynamic programming model for evaluation of agricultural management systems in Richmond County, Virginia. Agricultural Systems, 42(1-2), 127-152. 